\title{
Postmodernist Literature and Theatre From the Perspective of Intermedial (Meta)reference
}

\author{
N. Rarenko \\ Kyiv National Linguistic University, Kyiv, Ukraine \\ Corresponding author. E-mail: natalie.rarenko@gmail.com
}

Paper received 20.11.20; Accepted for publication 27.11.20.

\section{https://doi.org/10.31174/SEND-Ph2020-241VIII72-11}

\begin{abstract}
The article explores the phenomenon of theatricality as a form of intermediality in postmodernist literature, with metareference viewed as an essential verbal means of its manifestation. Linguistic poetics and intermediality theory serve as the theoretical and methodological basis of elucidating verbal and textual manifestations of theatricality in postmodernist literary texts. From this perspective, the use of theatre-related metareferences in postmodernist fiction is explicated as a form of intermediality, which accentuates textual presence and imitation of theatre as a distinct medium in literary text. In this paper, the focus on intermedial metareferences is twofold - 1) analysis of metareferences that specifically mention or discuss media-specific qualities of theatre as a media-form; 2) discussion of metareferences to specific theatrical works (both real and fictitious). Special focus is given to eliciting manifestations of theatrical metareferences in such postmodernist novels as The Black Prince by Iris Murdoch and The Magus by John Fowles. The phenomenon of theatricality is discussed with regard to its stylistic potential to demonstrate an intermedial convergence between literary text and theatre as media forms. It is revealed that the manifestations of metareferences to theatrical art juxtapose the boundaries of reality and artifice, bring to the foreground the effect of theatricality.
\end{abstract}

Keywords: metareference, intermediality, postmodernism, linguistic poetics, theatricality.

Introduction. Over the years, the interface of literature and media has been in the limelight of literary studies and linguistic poetics. This tendency particularly resonates with the studies of postmodernist literature, and postmodern art in general, commonly characterized by the convergence of manifold genres, styles, and artistic forms. Central to this research is the notion of theatricality which, emerging at the bounder of literature and theatre, imbues literary text with theatrical conventions and effects. Given the multifaceted nature of this phenomenon, a critical framework for explicating various manifestations of theatricality in postmodernist fiction could be well provided by the theory of intermediality - a vast field of research on interconnectedness of contemporary media.

In the last decades, the theory of intermediality proved to be a theoretical and methodological starting point for many scholars interested in probing into the intersections between media that utilize distinctive semiotic codes and a variety of modes $[16 ; 20 ; 21]$. Within the realm of literature, various forms of media crossing are distinguished — from explicit discussions of an outside medium to its implicit imitation in literary text. An example of such an intermedial form is metareference, essentially viewed as a transmedial phenomenon produced at a 'meta-level' by a self-reference to mediarelated aspects of a concrete work (artefact) or to the entire system of media [22, p. 31]. In fact, the existence of metareferenciality ('metaization') is argued to have gained paramount importance in contemporary media and arts to an extent of metareferential turn (ibid.) over the past few decades.

In order to clarify the interplay of theatrical art and literature as two distinct media in the context of postmodernism, it seems essential to elaborate on the phenomenon of theatricality from the perspective of intermedial (meta)reference in its aesthetic and verbal formats. Despite the dominant role of theatrical practices throughout the history of human culture, intermedial manifestations of theatricality remain understudied within the scope of literary studies and linguistic poetics. Set against the outlined theoretical framework, this paper attempts to examine verbal and textual means of creating the effect of theatricality as an intermedial phenomenon in postmodernist literature that intermingles literary texture with intermedial (meta)references; in other words, approaching postmodernist literary text as containing self-references to its intrinsically theatrical nature and/or references to theatre as a distinct medium. Special emphasis is laid on eliciting instances of theatrical metareferences in such postmodernist novels as The Black Prince by Iris Murdoch and The Magus by John Fowles.

Literature review. In considering salient aspects of theatricality in postmodernist fiction, we would first look into how this complex phenomenon originated and what the way is of viewing it in other related areas of humanities. The word 'theatre' can be traced historically to the Greek word 'theatron' which, being derived from 'thea' ("show") or 'theâsthai' ("to look on"), was used to designate a place for watching cultural, political, athletic, cult, and religious events [9, p. 7]. Indeed, theatrical activities and rituals are widely considered as a vital factor in the socio-religious life of archaic communities [3, p. 3].

Transcending beyond the domain of the professional stage, theatrical practices are viewed as integral attributes of daily life — human beings are expected to act out their roles in games, trainings, and other forms of activities (ibid.). In humanities, the concepts of theatre and theatricality have acquired special significance in a variety of philosophical, political, and aesthetic contexts, including William Egginton's take on theatricality from the perspective of spatiality [5], Yuriy Lotman's idea of the theatre of everyday life [13] and Nikolai Evreinov's theory of theatrical instinct [7]. It must be admitted that things and events as such are not inherently theatrical; instead, the idea of theatricality in its various manifestations necessarily implies a set of definitive properties - aesthetic conventions and discursive practices, in C. Balme's terms, - that mark something as being theatrical [1, p. 89-90]. In turn, these properties "determine around which phenomena we place the 'frame' of theatrical apprehension" [ibid.: 90]. Theatricality is thus viewed as both "a discursive and performative practice by means of which theatre (as an institution and aesthetic form) intersects with wider cultural contexts" [ibid.: 90]. A similar position is taken by J. Féral and R. Bermingham, for whom theatricality 
appears not just a mere property, but rather an act of spectating — "a process of looking at or being looked at" [8, p. 98]. The effect of theatricality is ultimately achieved within a specific "framed theatrical space", whereupon it "transforms an event into signs in such a way that it becomes a spectacle" [ibid.].

At present, this prominence of theatrical medium and the effect of theatricality does not become obsolete with the emergence of new multimedia technologies and means of communication. In fact, it seems to gain an increasing importance in the context of postmodernism where "everything is theatricalized, but where the theatrical is more commonly presented through television, computers, film, and other technological and easily transmitted media" [11, p. 121]. It is especially observable in the realm of postmodernist writing with its various manifestations of media-related narratives and intermingling of artistic genres. To gain a better understanding of the interface between postmodernist fiction and theatre, it is thus crucial to look at those features of the postmodernist movement which are crucial for explicating the phenomenon of theatricality.

In Umberto Eco's sense, the notion of postmodernism is not chronologically bound and could be regarded as a "way of operating" in every historical period with its intrinsic characteristics of "irony, metalinguistic play, enunciation square" [4, p. 569]. Eco further makes an assumption whether postmodernism is "the modern name for mannerism as metahistorical category" [ibid.]. In today's theoretical discourse, reflections on the origins of postmodernism nonetheless comprise the time frame of the 20th century, especially in the context of the newest advances in media, political, and philosophical paradigms. Spurred on by the rise of "media and information society", postmodernist thinking subverts the classical conceptions of reality and representation, whereby the notion of "simulation" gains the paramount significance [14]. Simulation is traditionally associated with the concept of simulacrum, an image which displaces "precedes" in Jean Baudrillard's terms [2] — the reality. As Baudrillard argues, "the very definition of the real has become: that of which it is possible to give an equivalent reproduction [...] The real is not only what can be reproduced, but that which is always already reproduced. The hyperreal [...] We live everywhere already in an "aesthetic" hallucination of reality" [ibid., 146]. The idea of simulation, in which representations supplant reality, resonates with the postmodernist writing that incisively explores and juxtaposes the boundaries of fact and fiction, reality and artifice. As Fernando de Toro points out, "much of the discussion of PostModern culture and its artistic and cultural products, whether in architecture, music, narrative, painting, or theatre has centered on a number of specific characteristics, such as genre subversion and erasure, questions of gender and identity, erasure or neutralization of the fictional and the real, referential absence, inter- and autotextuality, rhizomatic writing, palimpsest, historicity, etc. However, the more one looks closely at the pragmatics of discourse production, the more one realizes that all the above mentioned characteristics are contained in one specific practice, that of simulation" [18, p. 418]. In this way of thinking, the idea of theatricality becomes increasingly important in the wake of crossing media borders and genres, bringing to the foreground certain theatrical qualities of literary text. In the words of Féral and Bermingham, "the emergence of theatricality in areas tan- gentially related to the theater seems to have as a corollary the dissolution of the limits between genres, and of the formal distinctions between practices, from dance-theater to multi-media arts, including happenings, performance, and new technologies" [8, p. 94]. The themes and forms of such postmodernist works showcase intermedial connections and references to the art of theatre in its various aspects - stage, carnival, spectacle, and performance. One way to explore how the realm of theatrical performance reaches literary text is to focus precisely on self-reflexive or metatheatrical elements as verbal signifiers of theatricality; in other words, how media borders between theatre and literature are blurred when literary text overtly reflects on its theatrical nature or utilizes intermedial references to theatrical world and artifacts.

Aim of the paper. Taking into account the abiding affinity of postmodernist writing with the intermedial presence of other media in fiction, the study of textual theatricality requires a systemic and comprehensive view grounded chiefly in the theory of intermediality. Thus, this paper aims to explore the notion of theatricality as a form of intermediality in postmodernist literary discourse, with metareference approached as an essential verbal means of its manifestation. To achieve this aim, the present paper primarily focuses on explaining the way literary text can attain theatrical qualities through the use of self-reflexive comments on its medial status as well as metareferences to theatre as a distinctive media form. From the perspective of literary linguistics, special attention is given to eliciting verbal and textual means of theatre-related (meta)referentiality in postmodernist literary text.

Research Materials and Methodology. The present study concentrates on explicating instances of theatrical (meta)references in postmodernist literary discourse, notably in Iris Murdoch's The Black Prince and John Fowles's The Magus. To perform this task, it is important to give an account of the research methods and theories which yield necessary information on intermedial phenomena and form a theoretical basis for exploring the notion of theatricality.

As a multifaceted phenomenon, intermediality has become an object of heightened interest in the vast field of interdisciplinary research and media studies $[6 ; 16 ; 20 ; 21]$. Central to the theory of intermediality is the idea that "media do not exist disconnected from each other" [17, p. 1], but rather form a constellation of intermedial connections and intersections. In this respect, the term "intermedial" generally refers to those "phenomena that (as indicated by the prefix inter) in some way take place between media" and thus "can be differentiated from intramedial phenomena as well as from transmedial phenomena (i.e., the appearance of a certain motif, aesthetics, or discourse across a variety of different media)" [16, p. 46]. Within the realm of literary text, intermedial encounters of other arts and media have frequently been emphasized in stylistics and literary studies [19]. According to Werner Wolf, the notions of "mediality" and "intermediality" are substantially rooted in "historical, as well as contemporary reality as is shown by the manifold cross-relationships which have occurred between what we today call literature and other media" [21], particularly the way intermedial presence is prominent in drama, lyric poetry, and epics. In this paper, intermediality serves as a theoretical framework that explains and describes intermedial presence of theatre in postmodernist prose, i.e. how literary text 
integrates and imitates theatrical artistic forms of representation.

Taking into consideration this approach, our understanding of literary theatricality stems from the intracompositional type of intermediality, which is "discernible within the work in question where the intermedial relation is additionally an integral part of its signification" [ibid.]. One way through which such type of intermediality could manifest the effect of theatricality in literary text is the use of intermedial references to theatre as a media form [ibid.]. It means that literary text makes explicit references to theatre or implicitly imitates its presence verbally and textually. More precisely, such references may take on the form of intermedial metarefrences, which is especially true of postmodernist writing with its excessive use of self-reflexivity and metanarrative.

On the one hand, metanarrative comments have the potential to strengthen "the illusion of authenticity" of literary texts and thus "put across a convincing picture of a world" in Monika Fludernik's parlance [10, p. 61]. Contrary to enhancing the illusionistic effect of a narrative, some metanarrative elements may also cast doubt on its credibility, since "such comments also give the impression that the narrative discourse is a constricted account (fictio) or that the story is only made up (fictum)" [ibid.]. These illusionistic and artificial qualities of a narrative constitute an integral aspect of postmodernist writing, bringing to the foreground a certain degree of theatricality.

In order to lucidly analyze the effect of metatheatrical elements in postmodernist texts, it is also necessary to consider this problem within the scope of intermediality studies. Generally speaking, the notion of metarefrence designates "a special, transmedial form of usually non-accidental selfreference produced by signs or sign configurations which are (felt to be) located on a logically higher level, a 'meta-level', within an artefact or performance; this self-reference, which can extend from this artefact to the entire system of the media, forms or implies a statement about an object-level, namely on (aspects of) the medium/system referred to" [22, p. 31]. It is thus possible to infer that the use of self-reflexive comments and metareferences to other media within the domain of literary text amplifies the effect of metaawareness about its intermedial status. On this ground, an indepth consideration of theatricality forms in postmodernist literary text requires a comprehensive analysis of intermedial metareferences to theatre-related phenomena as one of its essential manifestations. To outline the specificity of theatricality in postmodernist literary texts, it is necessary to give an account of the verbal means which are used to manifest theatrical metareferences using the tools of text interpretation and literary linguistics.

Discussion of Research Results. As mentioned above, postmodernist fiction offers a plentitude of literary texts abundant in media-related elements and self-reflexivity. In this section of the paper, we will be eliciting textual manifestations of theatricality in postmodernist prose in twofold manner: 1) analyzing instances of metareferentiality that specifically showcase or discuss media-specific qualities of theatre as a form of media and artistic production; 2) discussing the use of metareferences to specific theatrical/ dramatic works (both real and fictitious).

In considering postmodernist representations of metareferentiality, John Fowles's The Magus is perhaps one of the most distinctive examples of the way theatrical me- tareferences pervade the narrative and compositional structure of the entire text. The plot of The Magus is centered around the bewildering events on a small Greek Island where Nicholas Urfe accepts a post of an English teacher. As the plot unfolds, the protagonist finds himself involved in an intricate play organized by Maurice Conchis, a mysterious island dweller, whose character evidently resembles a stagedirector being in charge of a spectacle. This sheer resemblance is achieved chiefly through the use of numerous metareferences to theatrical art, thereby endowing the described events and settings with qualities of a theatrical performance. Let's consider the verbal markers of theatrical metareferences pertaining to the speech of Maurice Conchis: "During the war, when I had a great deal of time to think, and no friends to amuse me, I conceived a new kind of drama. One in which the conventional separation between actors and audience was abolished. In which the conventional scenic geography, the notions of proscenium, stage, auditorium, were completely discarded. In which continuity of performance, either in time or place, was ignored. And in which the action, the narrative was fluid, with only a point of departure and a fixed point of conclusion. Between those points the participants invent their own drama" [12, p. 404].

In this excerpt, the description of the character's staging experience is rendered with the help of metareferences to the medium of theatre, particularly its scenic and acting properties. The accrual of theatre-bound lexis ("a new kind of drama","actors", "audience", "scenic geography", "proscenium", "stage", "auditorium", "performance", "action", "narrative", "participants") not only demonstrates the character's theatrical expertise but also amplifies the effect of mediaawareness about theatre as a distinct medium in the literary text. Maurice Conchis further goes on to explain: "There is no place for limits in the meta-theatre" [ibid., p. 406]; such commentary on the meta-theatrical nature of the story essentially contrasts the boundaries of illusion and reality, thus emphasizing the idea of theatricalized reality. Interestingly, the more the plot advances in displaying this meta-theatrical play, the more other characters, notably the protagonist Nicolas Urfe, are presented as actors performing their parts in a staged show or spectacle. This shift becomes evident not only in character's behaviour but also in their speech, gradually utilizing more theatre-specific verbal markers. As in, for instance, one of Nicolas Urfe's remarks on the landscape: "I strolled round the domaine, in the windless air. I waited in all the previous places. I kept on turning, looking backwards, sideways, listening. But the landscape seemed silent, and nothing and no one appeared. Even on the yacht there was no sign of life, though I noticed that the little power-boat was in the water, moored by a rope ladder amidships. The theatre seemed truly empty; and like all empty theatres, as the old devil no doubt intended, it became in the end both flat and a little frightening" [ibid., p. 408]. In the given fragment, the description of landscape is rendered by the metaphorical image of an empty theatre devoid of audience and even a slightest action. The repetition of lexical units "windless", "silent", "nothing", "no one", "no sign", "empty theatres", "flat" linguistically foregrounds the artificial, almost caricature-like, essence of the surroundings perceived from the perspective of Nicolas Urfe.

The prominence of metareferentiality and self-reflexivity in postmodernism writing takes on a different turn when it discusses or mentions some specific theatrical works and 
artefacts. To illustrate this tendency, let's focus on the instances of theatrical metareferences in Iris Murdoch's The Black Prince. In this novel, the plot revolves around Bradley Pearson, a middle-aged writer who struggles to achieve a breakthrough in his writing career. Over the chapters that follow, the protagonist strives to get away from the buzzing London and plunge into creating the greatest book of his lifetime. However, his aspirations are constantly interrupted by some mundane complications dealing with his family, friends, and an ex-wife. Amidst a sequence of these unfortunate events, Bradley Pearson finds himself in love with Julian Baffin, a young daughter of his closest friends. The novel consummately explores the tragic conflict which spurs from Bradley Pearson's affection and yearning hope for creating a true literary masterpiece. What draws our attention here in terms of theatricality is the way Shakespearean intertextuality is intricately interwoven into the novel's storyline William Shakespeare, particularly his play Hamlet, becomes one of the central literary topics discussed by Bradley Pearson and Julian Baffin: "The thing is a monument of words, it is Shakespeare's most rhetorical play, it is his longest play, it is his most inventive and involuted literary exercise" [15, p. 224], "He has performed a supreme creative feat, a work endlessly reflecting upon itself, not discursively but in its very substance, a Chinese box of words as high as the tower of Babel, a meditation upon the bottomless trickery of consciousness and the redemptive role of words in the lives of those without identity, that is human beings. 'Hamlet' is words, and so is Hamlet. He is as witty as Jesus Christ, but whereas Christ speaks Hamlet is speech" [ibid.], "Shakespeare cries out in agony, he writes, he dances, he laughs, he shrieks, and he makes us laugh and shriek ourselves out of hell. Being is acting. We are tissues and tissues of different personae and yet we are nothing at all" [ibid., p. 225].

As can be seen from these fragments, the protagonist is fascinated by Shakespeare's body of work, notably Hamlet, which is metaphorically rendered through the images of "a monument of words" and "a Chinese box of words". With regard to the latter, this implicit comparison to a Chinese box, a construction where each box is nested with a smaller one, underlines the multilayered, almost infinite, depth of this play. The multiplicity of its senses is further emphasized through the metaphor of the tower of Babel, a Biblical image commonly associated with the proliferation of human languages. Verbally, Bradley Pearson's reflections on Shakespeare's plays are characterized, on the one hand, by the use of professional lexis pertaining to the sphere of literary studies and humanities ("rhetorical play", "reflecting upon itself", "discursively"); on the other hand, the protagonist's speech is also metaphorically charged when he implicitly compares human beings to actors ("We are tissues and tissues of different personae") and their existence to acting ("Being is acting"). Interestingly, these meta-reflexive references to Shakespeare are further textually paralleled with the character's portrayal of Hamlet - Julian Baffin tries on the scenic costume of Hamlet before Bradley Pearson. For example, "She was dressed in black tights, black shoes, she wore a black velvet jerkin and a white shirt and a gold chain with a cross about her neck. She had posed herself in the doorway of the kitchen, holding the sheep's skull up in one hand" [ibid., p. 373], "All I needed was a skull, and then we found this lovely one. Don't you think it suits me? Alas, poor Yorick" [ibid.], "Don't I look princely?" [ibid.].
In these excerpts, the character's representation of Hamlet is highly schematic and artificial, "holding the sheep's skull up in one hand" as one of his most recognisable theatrical attributes. The "princely" image of the character is further reinforced through the famous quote "Alas, poor Yorick", which belongs to Hamlet, the Prince of Denmark. It is important to note that the similarities between Julian Baffin and Hamlet are superficial; as the plot advances, we may notice that it is Bradley Pearson who identifies himself with Shakespeare and, in particular, with Hamlet. At the dawn of his life, Bradley Pearson manages to produce the most significant book of his life titled Black Prince based on his life peripeteia leading up to imprisonment. This mirroring effect becomes even more explicit in the postscript when one of the protagonist's friends, Francis, points out the seemingly obvious correlation between Bradley Pearson's initials and his book title Black Prince. It seems that the discussed metareferences to Hamlet not only underpin the characters' affinity with Shakespeare's play on the narrative level but also serve the purpose of highlighting the textual presence of theatre as a distinct medium on the meta-level of textual organization. In this way, the literary text perpetually draws attention to its artificial status, with the art of theatre as its essential asset.

Conclusions. Taking into consideration the manifold manifestations of self-reflexive phenomena in postmodernism, it thus appears that the use of theatre-related metareferences reinforces the effect of theatricality in postmodernist literary discourse. On the meta-level of literary text, theatricality is rendered chiefly in the following way: 1) utilizing metareferences to theatre as a distinct medium, entailing the intricacies of producing, directing, staging, and performing a theatrical work of artefact; 2) employing metareferences to some specific theatrical/ dramatic figures and works (William Shakespeare as the pivotal theatrical figure), which adds an intertextual dimension to literary text. Such self-conscious references to the theatrical art render postmodernist literary texts in a more overtly theatrical vein, that is, attribute these texts with the formal qualities and conventions of a theatrical performance. In all of these instances, the effect of theatricality prolifically demonstrates an intermedial affinity between literary text and theatre as media forms; the latter being textually represented by means of meta-theatrical references. In a broader sense, it showcases the pervading role of theatricality as a behavioural, cultural, and artistic concept in postmodernist literary practice, where fictional characters and events are represented and perceived in terms of theatrical art.

Based on these implications, it seems possible to infer that the intermedial approach functions as a fruitful theoretical framework for explicating various forms of media intersections and connections, including those of theatre and literature. It would be of great interest and importance to further explore the intermedial convergence of theatre and literature on other levels of textual organization, including its complex narrative and compositional structures. Studies in verbal and textual manifestations of theatricality in literary discourse have the potential of giving an insight into other forms of intermedial relations and crossovers.

Acknowledgement. This paper is part of the project "Linguistics of Intermediality and the Challenges of Today: Polymodality of Mind, Intersemioticity of Text, Polylogue of Cultures" (Grant of Ministry of Education and Science of Ukraine, UkrRISTI Registration Number 0119U100934). 


\section{REFERENCES}

1. Balme, Christopher B. 2015. The Cambridge Introduction to Theatre Studies. NY: Cambridge University Press.

2. Baudrillard, Jean, 1982. Simulations. NY: Semiotext(e), Inc.

3. Devlin, Diana. 1989. Mask and Scene: Introduction to a World View of Theatre. Houndmills: Macmillan Publishers.

4. Eco, Umberto. 2014. Postscript to The Name of the Rose. NY: Houghton Mifflin Harcourt Publishing Company.

5. Egginton, William. 2003. How the World Became a Stage. Albany: State University of New York Press.

6. Elleström, Lars. 2010. Media Borders, Multimodality and Intermediality. Basingstoke, Hampshire, Palgrave Macmillan UK.

7. Evreinov, Nikolai. 2002. Demon teatral'nosti. [Demon of Theatricality]. M., SPb.: Letniy sad.

8. Féral, Josette and Ronald P. Bermingham. 2002. Theatricality: The Specificity of Theatrical Language. Madison: University of Wisconsin Press.

9. Fischer-Lichte, Erika. 2014. The Routledge Introduction to Theatre and Performance Studies. London-New York: Routledge.

10. Fludernick, Monika. 2009. An Introduction to Narratology. London-New York: Routledge.

11. Fortier, Mark. 1997. Theory/Theatre: An Introduction. LondonNew York: Routledge.

12. Fowles, John. 2004. The Magus. London: Vintage Books.

13. Lotman, Yuriy. 1992. Kultura i vzryv. [Culture and Explosion]. M.: Gnozis.

14. Mason, Fran. 2013. The A to Z of Postmodernist Literature and Theater. Lanham: Scarecrow Press, Inc.
15. Murdoch, Iris. 2019. The Black Prince. London: Penguin Random House.

16. Rajewsky, Irina O. 2005. "Intermediality, Intertextuality and Remediation: A Literary Perspective on Intermediality". Intermédialités (6): 43-64. https://doi.org/10.7202/1005505ar

17. Rippl, Gabriele. 2015. Handbook of Intermediality: Literature Image - Sound - Music. Berlin-Boston: Walter De Gruyter.

18. De Toro F. 1994. "Post-Modern Fiction and Theatricality: Simulation, Deconstruction, and Rhizomatic Writing". Canadian review of comparative literature: CRCL 21(3): 417-443. https://ejournals.library.ualberta.ca/index.php/crcl/article/view/33 $12 / 2651$

19. Vorobyova, Olga. 2017. "Virtual Narrative in Virginia Woolf's "A Simple Melody": Cognitive and Semiotic Implications." In Language - Literature - the Arts: A Cognitive-Semiotic Interface (14), edited by Elżbieta Chrzanowska-Kluczewska, Olga Vorobyova, 95-112. Frankfurt am Main: Peter Lang. https://doi.org/10.3726/b10692

20. Wolf, Werner. 1999. The Musicalization of Fiction: A Study in the Theory and History of Intermediality. Amsterdam-Atlanta, GA: Rodopi.

21. Wolf, Werner. 2011. "(Inter)mediality and the Study of Literature.” CLCWeb: Comparative Literature and Culture 13 (3). https://doi.org/10.7771/1481-4374.1789

22. Wolf, Werner, Katharina Bantleon and Jeff Thoss. 2009. Metareference across Media: Theory and Case Studies. AmsterdamNew Tork: Rodopi. 